\author{
Anna Szylar \\ Wydziat Nauk Spotecznych i Humanistycznych, \\ Państwowa Wyższa Szkoła Zawodowa \\ w Tarnobrzegu
}

\title{
Wzorce wychowania do życia w rodzinie przekazywane dziewczętom w szkołach klasztornych (XVII-XIX w.)
}

\begin{abstract}
Patterns of education for family life for girls in convent schools (XVII - half of XIXth century)

The paper aims to analyse the education and upbringing of girls in schools run by nuns in the period from the seventeenth to the mid-nineteenth century. It shows the elements of upbringing and education that shaped the attitudes and values considered the most important in family life. It discusses issues related to the education of girls in how to run and manage a household, how to do household work, how to manage the household expenditure. On the basis of school curricula the range of intellectual education, the development of personal standards (attitudes, behaviours and features of character) of women in this period will be shown.

These issues will be presented against a changing historical context, and will focus on girls from different social backgrounds.
\end{abstract}

Keywords: women education, convent schools

\section{Wprowadzenie}

Głównym celem niniejszego artykułu jest analiza wybranych zagadnień związanych z wychowaniem dziewcząt świeckich przez zakonnice w zakładanych przy klasztorach pensjach, szkołach i zakładach wychowawczych. Przedstawione zagadnienia związane są z kształtowaniem wzorców wychowania do życia w rodzinie. Rozważania odnoszą się do takich form działalności sióstr, jak organizacja wychowania, nauczania i opieki w okresie od XVII do początku XIX w. Nadmienić należy, że klasztory żeńskie były w tamtym okresie jedynymi instytucjami zajmującymi się szeroko rozumianą edukacją dziewcząt ${ }^{1}$. Od połowy XVIII w. zakładane były również świeckie pensje żeńskie. Ale niewielka ich

\footnotetext{
${ }^{1}$ Por. A. Szylar, Działalność wychowawczo-edukacyjna żeńskich zgromadzeń zakonnych w Małopolsce w okresie potrydenckim do 1815 roku, Kraków 2012, s. 26-27.
} 
liczba, wysoka odpłatność za pobyt oraz szeroka fala krytyki związana z realizowanymi tam wzorcami wychowania i edukacji, wpływała na ograniczenie zasięgu ich oddziaływania do arystokratek ${ }^{2}$.

Wychowaniem dziewcząt w klasztorach zajmowano się od czasów średniowiecza. Ponieważ na ziemiach polskich żeńskich domów zakonnych było nieporównywalnie mniej aniżeli w Europie Zachodniej, dlatego wychowankami były dziewczęta wywodzące się głównie z rodzin książęcych i rycerskich ${ }^{3}$. Mniszki traktowały tę formę własnej aktywności przede wszystkim jako sposób rekrutacji do zakonu. Z tego powodu edukacja ich ograniczała się do treści religijno-moralnych i praktycznego przygotowania do życia w klasztorze. Jeśli dziewczynka miała powrócić do życia świeckiego, to wychowanie klasztorne obejmowało kształtowanie w niej takich cech charakteru i umiejętności, które pozwalały w przyszłości pełnić przypisaną jej w społeczeństwie rolę - żony i matki ${ }^{4}$.

Aktywność opiekuńczo-wychowawczą przejawiały też niektóre grupy tercjarskie, rozwijające się dość licznie na ziemiach polskich w XIV i XV w. Powstawały one przy klasztorach męskich, a należące doń kobiety świeckie były w różny sposób zorganizowane i prowadziły zróżnicowaną działalność. Nierzadko była to opieka i pomoc ubogim i osieroconym dzieciom ${ }^{5}$. Wyspecjalizowaną opieką nad chorymi i ubogimi zajmowali się w okresie staropolskim duchacze. Żeńska gałąź tego zgromadzenia zakonnego trudniła się opieką nad małymi dziećmi oraz wychowywaniem osieroconych dziewcząt. Jednak ze względu na znikomą liczbę klasztorów duchaczek, zasięg ich oddziaływania był niewielki'.

Nowe ustawodawstwo, wprowadzone na soborze trydenckim, oraz regulacje prawne przygotowane przez papieży i biskupów diecezjalnych, nadały od końca XVI w. nowy kształt życiu monastycznemu kobiet. Grupy tercjarek należało rozwiązać, albo przekształcić je w mniszki klauzurowe. Realizacja tego postulatu przebiegała na ziemiach Rzeczypospolitej rozmaicie, ale w konsekwencji dość żywy ruch tercjarski został zahamowany ${ }^{7}$.

Wszystkie istniejące klasztory oraz nowe fundacje mogły mieć charakter wyłącznie klauzurowy. Zgodnie z tym przesłaniem zakonnice powinny zrezygnować z dotychczasowej pracy wychowawczej. Tak się jednak nie stało, ze względu na istniejące w kon-

${ }^{2}$ H. Kołłątaj, Stan oświecenia w Polsce w ostatnich latach panowania Augusta III (1750-1764), Kraków 1905, s. 127-128.

3 Por. J. Kłoczowski, Wspólnoty zakonne w średniowiecznej Polsce, Lublin 2010, s. 184-187; P. Gąsiorowska, Klaryski z dynastii Piastów, „Nasza Przeszłość” t. 94, 2000, s. 119-134.

${ }^{4}$ M. Bogucka, Białogłowa $w$ dawnej Polsce, Warszawa 1998, s. 153 i nast.

${ }_{5}$ A. Szylar, Działalność wychowawczo-edukacyjna..., s. 29-30. Tam też w przypisie 20 przedstawione zostały najważniejsze pozycje bibliograficzne na ten temat.

${ }^{6}$ Por. K. Antosiewicz, Zakon Ducha Świętego de Saxia w Polsce średniowiecznej, „Nasza Przeszłość” t. 23, 1966, s.192-196; eadem, Opieka nad chorymi i biednymi w krakowskim szpitalu Świętego Ducha (12201741), „Roczniki Humanistyczne” t. 24, 1978, z. 2, s. 51-65; A. Szylar, Pomoc dziecku w sytuacji kryzysowej - doświadczenia historyczne, w: Pomoc dziecku i rodzinie w sytuacji kryzysowej. Teoria, historia, praktyka, red. I. Kurlak, A. Gretkowski, Stalowa Wola-Sandomierz 2008, s. 171-179; eadem, Działalność wychowawczo-edukacyjna..., s. 98-99.

${ }^{7}$ A. Szylar, Działalność wychowawczo-edukacyjna..., s. 33 i nast. 
wentach tradycje edukacyjne. Ponadto dziewczęta świeckie, wychowywane w klasztorach, mogły odegrać znaczącą rolę w realizowanej w okresie potrydenckim walce z reformacją i utrwalaniem katolicyzmu.

Dlatego wychowywanie i edukacja dziewcząt świeckich pozostały w dalszym ciągu jedną z form działalności mniszek, zmianie uległy zasady organizacji tego procesu. Najistotniejszą kwestią było oddzielenie zakonnic od wychowanek, przeznaczenie dla tych ostatnich osobnych pomieszczeń mieszkalnych w obrębie klauzury i zakaz wzajemnego kontaktowania się. Do opieki nad dziewczętami wyznaczona została jedna zakonnica mistrzyni panien świeckich, która miała wyłączne prawo do przebywania z nimi. W razie potrzeby mogła być wyznaczona do pomocy jeszcze jedna zakonnica. Czas pobytu na pensji nie był normowany żadnymi odgórnymi przepisami, a termin oddania córki na wychowanie i okres pobytu uzależniony był od woli rodziców. Zgody na przyjęcie udzielała przełożona, ale o przekroczeniu klauzury decydował duchowny, sprawujący obediencję nad danym domem zakonnym. Obowiązywał zakaz opuszczania klauzury, odwiedziny rodziców i krewnych odbywały się wyłącznie w furcie klasztornej. Szkoła stanowiła zatem wydzieloną klauzurę w klauzurze, każde jej opuszczenie i powrót wiązały się z uzyskaniem stosowego pozwolenia. Przedstawiony powyżej sposób organizacji pensji był całkowicie odmienny od praktykowanego w okresie przedtrydenckim, kiedy to poszczególne zakonnice przyjmowały wychowanki indywidualnie i same sprawowały nad nimi opiekę ${ }^{8}$.

Kolejne zmiany organizacyjne wprowadzone zostały w okresie zaborów, miały one związek z rozwijanymi w oświeceniu nowymi ideami organizacji państw i społeczeństw oraz postrzeganiem roli Kościoła katolickiego i zakonów. Najpierw wdrożono je na ziemiach polskich pod panowaniem austriackim, potem pruskim, a następnie rosyjskim ${ }^{9}$. Istotne znaczenie dla procesu edukacji dziewcząt w szkołach klasztornych miał obowiązujący od 1810 r. w Księstwie Warszawskim Regulament pensji i szkót płci żeńskiej ${ }^{10}$. Regulował on kwestie organizacji szkół i zakres kształcenia dziewcząt, wzorowano się na nim również w Królestwie Polskim w pierwszym okresie jego istnienia ${ }^{11}$.

Reforma szkół żeńskich obejmowała oddzielenie szkoły od pensji, ta ostatnia pełniła rolę dzisiejszego internatu. Wprowadzono system klasowo-lekcyjny, podział na semestry, programy nauczania, egzaminy po każdym semestrze zimowym i letnim oraz promocje do kolejnych klas. Uczennice mieszkające w pensjonacie przebywały tam pod opieką świeckiej guwernantki lub zakonnicy. Do szkoły uczęszczały nie tylko one, ale też dziewczęta dochodzące. Nauczycielkami mogły zostać osoby zakonne i świeckie, posiadające

\footnotetext{
8 Ibidem, s. 36 i nast.

9 Ibidem, s. 109 i nast.; A. Szylar, Szkoła dla dziewcząt $w$ klasztorze benedyktynek $w$ Staniątkach $w$ dobie reform józefińskich, w: Szkoła polska od średniowiecza do XX wieku między tradycja a innowacja, red. I. Szybiak, A. Fijałkowski, J. Kamińska, Warszawa 2010, s. 204 i nast.

${ }^{10}$ Regulament pensji i szkół ptci żeńskich z 9 III 1810 r., w: Źródła do dziejów wychowania i szkolnictwa w Polsce z doby Izby Edukacji Publicznej 1807-1812, opr. Z. Kukulski, Lublin 1931, s. 510-523.

11 A. Winiarz, Szkolnictwo Księstwa Warszawskiego i Królestwa Polskiego (1807-1831), Lublin 2002, s. 318-328; A. Szylar, Działalność wychowawczo-edukacyjna..., s. 126 i nast.
} 
certyfikat zaliczenia wymaganych egzaminów i dopuszczenie do prowadzenia lekcji. Nadzór nad wszystkim szkołami zakonnymi sprawowały władze świeckie.

Sposób wychowania i zakres nauczania oraz decyzja o oddaniu córki do wybranej szkoły powiązana była z przynależnością społeczną dziewcząt. Do schyłku XVIII w. najzamożniejsze i najbardziej wpływowe rodziny posyłały swoje córki do szkół uznawanych za bardziej renomowane, prowadzone przez wizytki i benedyktynki, w tym również sakramentki. Spotykamy je również w szkołach klasztornych norbertanek, cysterek i klarysek, zdarzały się u bernardynek i brygidek. Zresztą, u tych ostatnich przebywało na wychowaniu dużo córek szlacheckich zarówno bogatszej, jak i biedniejszej szlachty. Ale przykładowo w szkołach krakowskich znajdujemy też córki zamożnych mieszczan.

Zakonem typowo nauczającym były prezentki. Rekrutacja uczennic obejmowała dziewczęta zamożniejsze, zdolne do opłacenia swego pobytu oraz biedne, przebywających na tzw. miłosierdziu. Fundatorka poleciła nauczać również dziewczęta dochodzące na naukę z miasta ${ }^{12}$.

Funkcjonowały też zgromadzenia zakonne zajmujące się pracą wychowawczą wśród ubogich i osieroconych dzieci. Były to przede wszystkim szarytki, zakładające przytułki i sierocińce, wspomniane wcześniej duchaczki, następnie katarzynki zamieszkujące na Warmii czy mariawitki na Litwie, dla których celem była pomoc neofitkom ${ }^{13}$.

\section{Wzorce wychowania religijnego}

Zalecenia odnoszące się do wychowania dziewcząt w szkołach klasztornych odnajdujemy w niektórych dokumentach normatywnych zakonów żeńskich. Jedną z pierwszych regulacji potrydenckich stanowiła Reguła św. Benedykta z konstytucjami chełmińskimi, przygotowana dla benedyktynek, a zatwierdzona na przełomie XVI i XVII w. ${ }^{14}$ Zamieszczone w tekście wskazówki na temat organizacji szkół klasztornych i wychowania dziewcząt stanowiły wzorzec dla późniejszych unormowań, wprowadzanych przez biskupów i prowincjałów.

Cel edukacji został w Regule jasno sprecyzowany. Panny należało wychowywać Panu Bogu na chwate, rodzicom na pocieche, duszom ich na pożytek zbawienny ${ }^{15}$. Podczas pobytu w szkole klasztornej mistrzyni musiała pracować nad rozwijaniem i pogłę-

12 R. Gąsior, T. Matuła, Szkoła Sióstr Prezentek w Krakowie w latach 1627-1918, Lublin 1998, s. 101-106.

13 A. Schletz, Historia sióstr miłosierdzia w Polsce, „Nasza Przeszłość” t. 12, 1960, s. 59-173; A. Jurczak, Zgromadzenie Sióstr Miłosierdzia św. Wincentego á Paulo sług ubogich chorych. Prowincja Warszawska, Lublin 2000; A. Szylar, O Siostrach Miłosierdzia, które „...Onemu stużyć będą w osobie ubogich, chorych, więźniów, sierot lub innych..." - wybrane przykłady w ujęciu historycznym [w druku]; B. G. Śliwińska, Dzieje Zgromadzenia Sióstr Świętej Katarzyny Dziewicy i Męczennicy, Olsztyn 1998, s. 142-149; M. Borkowska, Dzieje zgromadzenia Mariae Vitae czyli mariawitek, „Nasza Przeszłość” t. 79, 2000, s. 107-152.

${ }_{14}$ Reguła Świętego Ojca Benedykta z łacińskiego przettumaczona, i z reformacyja porządków chetmińskiego, toruńskiego, żarnowieckiego, nieświeskiego i inszych wszytkich w Królestwie Polskim tejże reformacyjej i Reguly S. Benedykta, które te raz sa i napotym zjednoczone będa, klasztorów panieńskich, Kraków 1606.

${ }^{15}$ Reguła Świętego Ojca Benedykta..., s. 137. 
bianiem religijności wychowanek, aby łacniej i lepiej powinności chrześcijańskie poznawać mogły, które w ćwiczeniu i wypetnianiu cnót świętych zawisły, a przy powinnościach chrześcijańskich uczyć ich zarazem będzie obyczajów ich stanowi panieńskiemu właściwie należacych ${ }^{16}$.

Dla szerszego rozeznania problemu warto porównać teksty z innych zakonów i klasztorów, zawierające zalecenia dotyczące wychowania religijnego. U prezentek obowiązywały Ustawy Domu Panieńskiego i zgodnie z zamieszczonym tam zapisem dziewczęta uzyskać miały wychowanie dobre i z młodości ćwiczone były nie tylko w bojaźni Bożej, [ale] w uczciwych i chrześcijańskich obyczajach ${ }^{17}$. Przyjęty przez prezentki w XVII w. ideał wychowania dziewcząt był wciąż aktualny w XVIII stuleciu. Biskup krakowski Konstanty Felicjan Szaniawski, erygując w nowym miejscu klasztor prezentek przypomniał siostrom, aby miłość $i$ pobożność $w$ ćwiczeniu i nauce panienek tak z obligacji przyjętych jako też sobie na czas powierzonych wypetnity $i$ one wprzód w bojaźni Bożej i tajemnicach wiary, potym $w$ czytaniu, pisaniu i inszych naukach stanowi panieńskiemu przyzwoitych informowaty $i$ ćwiczyly ${ }^{18}$. Podobne treści zawierał również tekst z połowy XVII w., sporządzony przez fundatorkę wizytek warszawskich, królową Ludwikę Marię. Zleciła ona siostrom prowadzenie szkoły dla wychowanek świeckich, w której miały zaszczepić i wpoić uczennicom ducha bojaźni Bożej i szacunek do pracy ${ }^{19}$.

Analogiczne postulaty odnajdujemy w dokumentach z początków XIX w. Kazimierz Wohlfeil, sprawujący urząd generalnego inspektora szkół ludowych w Krakowie w latach 1802-1810 ${ }^{20}$ zalecał: całe wychowanie panienek powinno by się zasadzać na przepisach, na [podstawie] których by się nauczyly moralności, porządku, gospodarstwa i dozoru", przy czym przez pierwsze z pojęć rozumiał zachowanie praw religii i natury $i$ wpajanie tych samym dzieciom ${ }^{21}$. Do wspomnianych powyżej wzorców wychowania dziewcząt nawiązują też założenia Regulamentu z 1810 r. Tam bowiem znajdujemy zapis, że wychowanie moralne opiera się na religii, która będąc najważniejszym punktem wychowania zaszczepi $w$ duszy młodzieży bojaźń Boga nagradzającego za cnoty a karzacego występi w teraźniejszym i przyszłem życiu ${ }^{22}$.

${ }^{16}$ Ibidem, s. 138.

17 Ustawy Domu Panieńskiego przez szlachetna i pamięci pobożna matronę, Zofia z Maciejowic Czeska pod tytułem Ofiarowania Najświętszej Panny Maryjej w Krakowie roku P. 1623, dnia 11 maja fundowanego. Wedlug reguly św. Eufemii, za pozwolenie ojca świętego Aleksandra VII przez J.O. Jego Mości X. Piotra Gembickiego przeniesione, a przez sukcesora jego J.O. J. X. Andrzeja Trzebnickiego podane (13 I 1660), powtornie przez J.O. Xcia J.M. Jana z Małachowic Małachowskiego (1698) reasumowane, Kraków 1698, k. 28.

${ }^{18}$ Cyt. za R. Gąsior, T. Matuła, Szkoła ...., s. 393.

19 B. Fabiani, Warszawska pensja panien wizytek w latach 1655-1680, w: Warszawa XVI-XVII wieku, z. 2, Warszawa 1977, s. 187.

${ }^{20}$ W. Caban, Szkolnictwo poczatkowe w Galicji Zachodniej za panowania austriackiego i w czasach Księstwa Warszawskiego, w: Galicja w Księstwie Warszawskim: 200 rocznica, red. H. Żaliński, H. Chudziło, Kraków 2009, s. 78-79.

${ }^{21}$ Biblioteka Jagiellońska (dalej BJ), rkps Uwagi niżej podpisanego nad wychowaniem panienek w klasztorach krakowskich, 1803, K. Wohlfeil, sygn. 5171/36, k. 304.

${ }^{22}$ Regulament pensji..., s. 510. 
Z przedstawionych zapisów jasno wynika, że wychowanie dziewcząt w szkołach klasztornych w omawianym okresie opierało się na religijnym wzorcu wychowania, stanowiącym fundament nauczania moralności i obyczajów.

Ideał wychowania religijnego realizowano we wszystkich szkołach klasztornych w podobny sposób, a przez cykliczne powtarzanie tych samych czynności dążono do utrwalenia pożądanych zachowań. Każdy dzień rozpoczynano i kończono modlitwą. Na rano przewidziane były wspólne pacierze odmawiane pod okiem mistrzyni, następnie udział we mszy św., a w godzinach popołudniowych litanie. Pacierz wieczorny i rachunek sumienia były ostatnimi czynnościami w ciągu dnia, po nich obowiązywało milczenie i dziewczęta udawały się na wieczorny odpoczynek. W ciągu dnia modlitwą rozpoczynano też i kończono wszystkie lekcje oraz posiłki. W ten sposób starano się ukształtować w uczennicach nawyk częstej a krótkiej modlitwy.

W niedziele i dni świąteczne oprócz mszy św. i nabożeństw związanych z danym świętem, dziewczęta uczestniczyły w katechizacji prowadzonej przez kapelana klasztoru lub jakiegoś kaznodzieję. Nauki te stanowiły pogłębienie i ugruntowanie wiedzy przyswojonej w szkole klasztornej oraz służyły poznaniu przymiotów dobrej kobiety-chrześcijanki. Mistrzyni w szkole omawiała z wychowankami wszystkie wątpliwości i problemy, odpytywała z właściwego zrozumienia i zapamiętania treści katechezy, wskazywała na konkretnych przykładach pozytywne i negatywne wzorce zachowań oraz określała ich konsekwencje dla życia doczesnego i wiecznego. W ten sposób dziewczęta miały poznać istotę życia w pobożności i cnocie, zrozumieć przesłanki przestrzegania przykazań Bożych i kościelnych, i na tyle mocno wdrożyć je sobie w pamięć, aby efekty nauki pozostały trwałe przez całe życie.

Nieodłącznym elementem wychowania religijnego było uczestnictwo w rekolekcjach wielkopostnych i sakramentach. Dziewczęta przygotowywano do spowiedzi, Komunii św. i bierzmowania, a także uczono zachowania się w obliczu śmierci. Modlitw i tekstów odmawianych w zależności od przyjmowanych sakramentów, uczono się na pamięć. Powtarzano je często $w$ celu utrwalenia, a odmawianie ich razem przez wychowanki miało ukształtować nawyk wspólnej modlitwy domowej. Zwracano szczególną uwagę na właściwą postawę ciała podczas modlitwy, wypowiadanie słów powoli i z należytym szacunkiem. Praktykowano powstrzymywanie się od posiłków w wigilię Komunii św. oraz duchowe przygotowanie się do przyjęcia sakramentu przez wyciszenie się i kontrolowanie własnych zachowań. Usilnie dbano, aby zasada ta stała się normą nie tylko podezas pobytu w szkole klasztornej, ale również i w późniejszym życiu świeckim ${ }^{23}$.

Najpełniejszy wzorzec wychowania religijnego zawarty został we wspomnianej już Regule benedyktynek. W jej tekście czytamy, że powinności chrześcijańskie opierały się na trzech cnotach Boskich: wierze, nadziei i miłości oraz czterech, należących do pobożnych obyczajów: roztropności, sprawiedliwości, mężności i wytrzymałości. Należało je

${ }^{23}$ Por. A. Szylar, Działalność wychowawczo-edukacyjna..., s. 196-198; eadem, „Naprzód zaraz wstana, kiedy ich obudza...", czyli panny świeckie na edukacji u wizytek warszawskich w XVIII wieku, w: Per mulierem... . Kobieta $w$ dawnej Polsce $-w$ średniowieczu $i w$ dobie staropolskiej, red. K. Justyniarska-Chojak, S. Konarska-Zimnicka, Warszawa 2012, s. 222-224. 
tak mocno wpoić wychowankom, aby w natóg święty je sobie przywodzity ${ }^{24}$. Dziewczęta musiały mieć świadomość, że bez dogłębnego rozumienia i stosowania tych cnót niemożliwe było zbawienie człowieka. Uważano też, że jedynie skuteczne ich wdrożenie spowoduje, że w dorosłym życiu staną się one najważniejszą i niezmienną wartością. W pouczeniach skierowanych do mistrzyń zalecano: panien świeckich, które rodziny na naukę oddają, tak uczyć i szanować w Panu Bogu rozkazujemy, żeby i na świecie po nich znać byto, że się w klasztorze chowaty $i$ ćwiczyty ${ }^{25}$.

\section{Wzorce wychowania obyczajowego i moralnego}

Nierozerwalny związek z wychowaniem religijnym miało kształtowanie moralności, charakteru i osobowości dziewcząt oraz wdrażanie do zachowania obyczajów. Sztywne regulaminy i ustalony rytm dnia, odpowiednie rozplanowanie czasu na modlitwę, naukę, pracę i odpoczynek wpływały na wyrobienie dyscypliny i racjonalnego gospodarowania czasem.

Każda z dziewcząt musiała nauczyć się samodzielnie ubierać i szanować odzież, ponieważ w przyszłości dbałość o garderobę domowników miała stanowić jedną z głównych powinności pań domu. Ubiory powinny być czyste i skromne. Do codziennego użytku wystarczały podniszczone suknie, musiały być jednak schludne i pocerowane ${ }^{26}$. Strój domowy miał się różnić od wyjściowego, chociaż ten ostatni nie powinien być zbyt wymyślny. U wizytek zwracano szczególną uwagę na wygląd dziewcząt udających się do rozmównicy na spotkanie z osobami przyjezdnymi. Panna taka powinna być ubrana jak najprzystojniej, wystrzegając się jednak zbytniej próżności w stroju, jako to na przykład trefienia [włosów], szyi obnażania ${ }^{27}$.

Potwierdzenie tej praktyki odnajdujemy też w zaleceniach biskupa Konstantego Kazimierza Brzostowskiego z 1710 r., który pisał: odzienie panien ma być takie, aby panieńskiej skromności $i$ wstydowi przynależało [...] aby pomienione panny $w$ czarnym albo ciemnym albo w biatym odzieniu $i$ to nie jedwabnym chodzity, i żeby dla żadnej przyczyny bogatszego stroju nie zażywaty, ani kędziorów, zausznic i innych białogłowskich wymystów nie nosity ${ }^{28}$. Biskup krytykował te zakonnice, które wbrew obowiązującym przepisom i obowiązkom niemało czasu trawia na strojeniu panien świeckich, omieszkiwujac powinności i zabaw zakonnych ${ }^{29}$. Skromność i schludność w ubiorach oraz zachowanie

${ }^{24}$ Reguła Ojca Świętego Benedykta..., s. 139.

25 Ibidem, s. 138.

${ }^{26}$ Suknie „dodzierać ma każda i tym jednak sposobem, aby nie były zbyt poszarpane”. Archiwum Sióstr Wizytek w Warszawie (dalej AWiWa), rkps Kutumiarz i directorium dla sióstr zakonnic Nawiedzenia NMP z francuskiego na polski przetłumaczony, sygn. A 15, s. 342 .

27 Ibidem.

${ }^{28}$ K. K. Brzostowski, Zebranie z listów papieskich, które się bulla zowia z conciliów, wyroków, odpowiedzi i różnych praw kościelnych dla nauki ww panien zakonnych do druku podane roku Pańskiego 1710, Wilno 1710 .

29 Ibidem. 
higieny stanowiły zasadę wychowania klasztornego. Mistrzyni miała utrwalać w wychowankach nawyki z tym związane, zwłaszcza w częstym czosaniu i myciu, tego z pilnościa strzegać [strzec], żeby która przez jakie niedbalstwo do złego zdrowia, do zaplugawienia głowy, do krost, do pogubienia szatek swoich nie przyszła ${ }^{30}$.

Nieodłączną cechą charakteru kobiety powinna być wstydliwość. Dlatego podczas toalety i zmiany odzieży dziewczęta musiały zachowywać się powściągliwie, ponadto rozbierać się będą i ubierać z jak największą skromnościa, nieodkrywając się żadna miarą, ani też w samej koszuli albo odzieniu [...] chodzić nie będa ${ }^{31}$.

Uczono je też zachowania porządku w swoim najbliższym otoczeniu. Każda z dziewcząt miała nauczyć się samodzielnie ścielić łóżko, układać odzież i wszystkie przedmioty osobiste na miejscu ich przeznaczenia ${ }^{32}$.

Szkoła klasztorna była też miejscem nauki norm zachowania i obyczajów, stanowiących kanon wychowania niewiasty. Do czasu wprowadzenia reformy szkół żeńskich nauka odbywała się przez bezpośredni kontakt z mistrzynią, słuchanie jej pouczeń oraz analizowanie różnych zachowań, w XIX w. wprowadzono naukę obyczajową jako przedmiot.

Interesujący wydaje się zakres nauczania obowiązujących dziewczęta zasad obyczajowych. Podczas chodzenia należało poruszać się dostojnie, bez pośpiechu, nie otwierać ust ani ich mocno nie zaciskać, bo tylko takie ułożenie ciała świadczyło o skromności i wstydliwości. Ramiona należało wyciągnąć nieco do tyłu, ręce ułożyć na piersiach, a podczas poruszania się stawiać krótkie i niezbyt szybkie kroki. Niedopuszczalne było powłóczenie nogami, maszerowanie, potrząsanie głową i rękoma. Postawa ciała powinna być dostojna, ale też przyjemna $i$ wesoła, lecz bez pustoty; niewinność lub szczerość z twarzy prawie poczytać sie powinna ${ }^{33}$.

Dziewczęta uczono, że ułożenie głowy określało stan emocjonalny. Najwłaściwiej było ją trzymać prosto, spoglądając przed siebie nieco spuszczonymi oczyma, ponieważ głowa zwieszona do przodu oznaczała rozpacz, a pochylona na bok oznaczała smutek i zmartwienie.

Ważne było też odpowiednie siadanie. Zakładanie nogi na nogę świadczyło o braku wychowania, ale też przyjmowanie postawy skulonej nie należało do dobrego tonu. W rozmowach należało wysławiać się krótko i rzeczowo, nikogo nie obrażać, nie przerywać rozmówcom ich wypowiedzi, a na zadawane pytania odpowiadać konkretnie.

${ }^{30}$ Reguła Ojca Świętego Benedykta..., s. 138.

31 AWi.Wa., rkps Rozporządzenie dla Ich Mość Naszych Panien Świeckich jako się powinny sprawować, XVIII w., sygn. F 1, s. 14.

32 „Jeszcze uczyć ich będzie, aby ochędostwo miłowały, tak około siebie, jako i na wszystkich miejscach, kędy [w]spólnie mieszkają, aby w chowaniu i chędożeniu swych rzeczy opatrzone były i porządnie. Czego się snadnie nauczą, kiedy Panna Mistrza sama strony ich szat, łóżek i inszych rzeczy rachunek częsty z niemi będzie czyniła". Archiwum Sióstr Klarysek Krakowskich (dalej AKKr), rkps Piotr Gembicki z łaski Bożej i Stolicy Apostolskiej Biskup Krakowski, książę siewierski, wielebnej w Chrystusie Panu Pannie Ksieni i wszystkiemu zgromadzeniu Panien zakonnych pod Regułą świętej Klary [1643], sygn. A 17, s. 18.

${ }^{33}$ AKKr., rkps Przepisy dla szkół normalnych krakowskich panien świeckich przy klasztorze WW. PP. Franciszkanek od roku 1804, sygn. SzP 10. 
W towarzystwie można okazywać wesołość, ale nigdy nie przekraczać granicy dobrych obyczajów. Za brak wychowania uznawano szeptanie do ucha w obecności innych osób, nieskromne rozglądanie się wokół, wpatrywanie się w inne osoby oraz strojenie min, nadymanie ust i marszczenie czoła. Do pożądanych wdzięków każdej kobiety należało zachowanie w swoim otoczeniu ciszy i spokoju oraz powściągliwości w postawie, ponieważ te przymioty świadczyły o dobrym wychowaniu. Twierdzono, że ozdobę panny stanowić powinna powaga, nie zaś grubiaństwo ani zbytnia dwornośćc ${ }^{34}$.

Do zewnętrznych form postępowania należały zasady dobrego zachowania się przy stole. Posiłki uczennice jadały wspólnie, miejsca przy stole zajmowano w wyznaczonej kolejności. Uczono je, że dobre wychowanie polega na nakładaniu na talerz małych porcji jedzenia nie wydzierając jedna drugiej większych czy lepszych kęsów, oraz zjadanie posiłków spokojnie i bez pośpiechu. Odejście od stołu możliwe było dopiero po udzieleniu na to zgody przez mistrzynią ${ }^{35}$.

Dbano o właściwe relacje i wzajemne kontakty pomiędzy wychowankami, ponieważ w przyszłości to one przekładały się na sposób życia w środowisku domowym i sąsiedzkim. Życie w zgodzie, bez kłótni, unikanie robienia sobie przykrości, skarżenia jedna na drugą, szkodliwego działania na rzecz drugich, kierowania się złością i nienawiścią były to wszystko negatywne cechy, które należało wyeliminować z zachowania ${ }^{36}$. Rolą mistrzyni było stworzenie takiej atmosfery w pensjonacie, aby panny wzajemnie się szanowały, pomagały sobie i wspierały się uprzedzając jedna druga w małych postugach, ustępujac swojej woli i inklinacji dla ukontentowania bliźniego ${ }^{37}$.

Uczono też posłuszeństwa wobec zwierzchności, która Bóg nad każdym postanowi ${ }^{38}$. Z przesłania tego wywodzono szacunek wobec osób starszych i obowiązek wykonywania wszystkich ich poleceń. Wychowawczy aspekt posłuszeństwa odnosił się do roli i miejsca w społeczeństwie i wykonywania w przyszłości powinności zgodnych z urodzeniem i zajmowaną pozycją społeczną.

Starano się rozwinąć u wychowanek umiejętność dochowywania tajemnic, ponieważ cecha ta odgrywała istotną rolę w całym życiu. Uświadamiano im, że plotkarstwo i rozpowiadanie negatywnych opinii na temat drugich osób stanowił bardzo zły nawyk, którego należy się oduczyć. Najbardziej potępianą cechą charakteru było kłamstwo. Dziewczęta były uczone, że kłamstwo jest grzechem i zawsze, wcześniej czy później zostanie ujawnione ${ }^{39}$.

Najtrafniej założenia wychowania i nauki moralnej sformułowały na swojej pensji duchaczki, które twierdziły: nauka zaś moralna zasadza się szczególnie na wysławieniu cnót zdobiacych i właściwych płci żeńskiej, jakiemi są: praca, skromność, oszczędność, łagodność, cierpliwość, litość i tym podobnych, równie jak na wystawieniu występów

\footnotetext{
34 Ibidem; Reguła Ojca Świętego Benedykta..., s. 143.

35 AWi.Wa., rkps F 1, s. 4-5.

36 Ustawy Domu Panieńskiego..., k. 1-27.

${ }^{37}$ AWiWa, rkps F 1, s. 16-17.

38 Ibidem..

39 Ibidem, s. 16-21.
} 
tym cnotom przeciwnych $i$ jakim sposobem osoby skłonne do nich pozbyć się ich $\operatorname{mog} a^{40}$.

Zgodnie z ideałem wychowania moralnego w szkołach klasztornych każda panienka ma być jako Anioł, dlatego też i obyczaje takie starać się powinna, które by Aniołom byly podobne i naśladować ich ${ }^{41}$. Wychowanie musiało być na tyle skuteczne, aby po opuszczeniu szkoły widać było, że dziewczęta przebywały i pobierały nauki w szkole klasztornej.

Jeśli porównamy założenia wychowawcze w zakresie nauki obyczajów i moralności, to na przestrzeni omawianego okresu były one bardzo zbliżone.

\section{Nauka robót kobiecych}

Nieodłącznym elementem wychowania klasztornego było przyzwyczajanie dziewcząt do codziennych zajęć, co dla niektórych było sprawą niezwykle trudną ze względu na odmienne nawyki, wyniesione z domów rodzinnych. Nieprzyzwyczajenie do jakiejkolwiek pracy fizycznej, niezdyscyplinowanie, kaprysy, brak podstawowych umiejętności związanych z ubraniem się, czy wykonaniem toalety, to zjawisko bardzo częste wśród panien świeckich wywodzących się z zamożnych rodzin. Pensja stanowiła dla wielu z nich prawdziwą szkołę życia. Zabronione było przyjmowanie wychowanek ze służącymi, dziewczęta same musiały nauczyć się dbałości o siebie i najbliższe otoczenie ${ }^{42}$. Zakres nauczanych umiejętności i prac fizycznych uzależniony był od pochodzenia społecznego, a dziewczęta należało uczyć tego, co jest zgodnie ze stanem ich i ich rodziców, lub co może stużyć im $w$ przyszłości $i^{43}$.

Niezmiernie istotnym elementem wychowania dziewcząt w szkołach klasztornych była nauka tzw. robót kobiecych, nazywanych też domowymi. Wdrażaniu do ich wykonywania i nauce umiejętności o charakterze praktycznym przypisywano większe znaczenie, aniżeli wiedzy intelektualnej. Wynikało to z przekonania, że ubogie uczennice będą mogły dzięki temu zapewnić sobie utrzymanie, a zamożniejsze w sposób świadomy prowadzić dom, zarządzać służbą i kontrolować wydatki.

W Ustawach obowiązujących w szkole prezentek czytamy, że dziewczęta powinny doskonalić swoje umiejętności $w$ robotach powierzchownych, stanowi panieńskiemu należacych ${ }^{44}$, zaś u norbertanek na Zwierzyńcu siostry powinny dbać, aby panienki $w$ rozmaitych robotach ręcznych zostaty ćwiczonemi ${ }^{45}$. Kazimierz Wohlfeil twierdził, że nauczenie dziewcząt właściwego planowania pracy w domu i gospodarstwie, porządku

\footnotetext{
${ }^{40}$ Archiwum Uniwersytetu Jagiellońskiego (dalej AUJ), sygn. SI 626, Odpowiedź na pismo [...] 13 II 1816.

${ }^{41}$ Reguła Ojca Świętego Benedykta..., s. 142.

42 AWiWa., rkps Zarządzenia ogólne władz szkolnych XIX w., sygn. F 3.

${ }_{43}$ BUJ, rkps Plan do wprowadzenia edukaciy szlachetnych panien majętnych, 1803, K. Wohlfeil, sygn. 5171/35, k. 296.

${ }^{44}$ Ustawy Domu Panieńskiego..., s. 28.

${ }^{45}$ AUJ, rkps K. Wohlfeiel do Prześwietnej Komisji Akademickiej 16 VIII 1809, sygn. SI 617.
} 
W ewidencji posiadanych sprzętów, prowadzenia rachunków oraz umiejętności wykonywania wszelkich prac domowych stanowić powinno zasadniczy element wychowania dziewcząt. Uważał, że tzw. dozór, będąc dusza każdego gospodarstwa, nie zależy na skrzętnem gderaniu bez celu, ale na dopilnowaniu, ażeby powierzona lub wyznaczona podległej osobie robota była w czasie przyzwoitym wykonana, wszakże opuszczenie się najmniejsze w raz dobrze wprowadzonym porzadku sprawuje nieład i zamieszanie. Do gospodyni należy czuwać nad obyczajami swej czeladzi. Strofowanie sprawiedliwe i kara, a nawet oddalenie gorszacej lub niepostusznej stużacej wraca raz zaprowadzony porza$d e k^{46}$. Aby właściwie przygotować dziewczęta do roli „pań domu” należało je nauczyć umiejętności praktycznych, przez przydzielanie do wykonania konkretnych zadań. W ciągu dnia poświęcano tym zajęciom przynajmniej dwie godziny, a po zreformowaniu szkół wprowadzono przedmiot o nazwie roboty i nauczano go kilka godzin tygodniowo.

We wszystkich szkołach klasztornych dziewczęta przez cały omawiany okres nauczano haftowania i szycia. Na pensji u wizytek wykonywano hafty i koronki, zaznajamiano uczennice ze sztuką cerowania ${ }^{47}$. U norbertanek na Zwierzyńcu na roboty ręczne przeznaczano kilkanaście godzin tygodniowo, dziewczęta uczono szycia, haftowania, przędzenia, a kunszt hafciarski tamtejszych zakonnic można do tej pory podziwiać dzięki zachowanym wytworom, datowanym na wiek XVII i XVIII ${ }^{48}$. Klaryski krakowskie nauczały swoje wychowanki dziergania ręcznego i tamborkowego, haftu na kanwie i zabkach, tak w kolorach, jak $i$ szydełkowe[go], jak i koronkowe[go], jak to attasikowe[go] ${ }^{49}$. Wykonywania haftów i koronek było zajęciem dość elitarnym, do bardziej powszechnych należało szycie. Dzielono je na lekkie i ciężkie, bieliźniarstwo, szycie białe i szycie sukien, a zakres nauki różnych jego rodzajów zależał od klasztoru, wieku dziewcząt i życzeń rodziców. W instrukcjach dla wizytek warszawskich czytamy, że mistrzyni może uczyć dziewczęta szyć chusty $i$ tym podobne rzeczy, a to dla nauki, ale tylko te panny, które nie sa obciążone inszemi zabawami ${ }^{50}$. Jeśli uczennica miała dużo dodatkowych zajęć, poprzestawano zapewne jedynie na nauce haftów i koronek. Ważną umiejętnością było przędzenie na kołowrotkach i „kręcenie nici”, podczas inspekcji w szkołach krakowskich wizytator nakazał zakupienie dodatkowych kołowrotków, aby wszystkie uczennice miały możliwość posługiwania się nimi. Ponadto w protokołach egzaminacyjnych spotykamy informacje o wykonanych przez dziewczęta pończochach, robotach szydełkowych i na drutach ${ }^{51}$.

46 BJ, rkps 5171/36, k. 304.

47 B. Fabiani, Warszawska pensja..., s. 180; AUJ, Raport o egzaminach i popisach publicznych szkół w objęciu miasta Krakowa znajdujących się [...] dnia 1 go lipca 1815 roku rozpoczętych, a 25 tegoż miesiąca i roku skończonych przez Michała Dymidowicza Konsyliarza Dyrekcji Edukacyi Narodowej, członka Dozoru Szkolnego Dep[artamen]tu Kraków [...], sygn. S I 620.

48 A. Rybak, H. Otorowska, Szkoła PP norbertanek w Krakowie, Warszawa, s. 11.

${ }^{49}$ AUJ, Przedmioty nauk w szkole płci żeńskiej PP. Franciszkanek u S. Andrzeja podczas danego popisu w Krakowie dnia 25 i 26 lipca 1814, sygn. SI 626.

${ }^{50}$ B. Fabiani, Warszawska pensja..., s. 180.

51 BJ, sygn. 5171/36, s. 304-305; AUJ, Szkoła św. Andrzeja 1814, sygn. SI 626. 
We wprowadzonych na początku XIX w. programach nauczania w klasztornych szkołach dla dziewcząt w Krakowie, zakres realizowanych robót kobiecych był dość szeroki. Wohlfeil uznawał, że dla dziewcząt uboższych lub miernego majątku [...] prócz elementarnej klasy bytoby dobrze [zorganizować] trzy wyższe, przy czym na wszystkich etapach kształcenia roboty ręczne byłyby weń zadaniem najgłówniejszym ${ }^{52}$.

Wspomniany program nauczania obejmował umiejętności związane z wdrożeniem i utrzymaniem porządku w gospodarstwie domowym oraz zasadami prowadzenia domu. Dziewczętom należało uświadomić, że podstawę dobrze prosperującego gospodarstwa domowego stanowi utrzymanie właściwego porządku sprzętów i narzędzi, zatrudnienie stosownej do potrzeb liczby czeladzi oraz bieżące prowadzenie rachunków. Umiejętności te były realizowane na różnych przedmiotach, głównie na lekcjach z rejestru dochodów i wydatków oraz podczas analizy traktatu o porządku i dozorze. W szkole panny miały się też nauczyć prowadzenia korespondencji, ćwiczono pisanie listów o tematyce gospodarczo-handlowej ${ }^{53}$. Zarządzanie gospodarstwem domowym powinno opierać się na gospodarności i oszczędności. Dlatego należało nauczyć się samodzielnego wytwarzania i wykonywania różnych rzeczy i prac, aby nie pomnażać kosztów utrzymania przez dokonywanie zbędnych zakupów. Stąd nie tylko robótki ręczne, takie jak hafty, szycie, dzierganie, ale też nauczenie dziewcząt przepisów kulinarnych, robienia mydła, krochmalu i świec, przędzenia na kołowrotkach, farbowania, przygotowania prostych leków, uprawa ziół, jarzyn i warzyw niezbędnych w domowej kuchni, stanowić powinny główny cel nauczania ${ }^{54}$. Umiejętności tych należało uczyć przez zaznajamianie z zasadami ich wykonywania, przepisywanie stosownych przepisów kulinarnych i różnych receptur, oraz organizowanie zajęć praktycznych.

Nie jesteśmy w stanie dokładnie określić, w jakim stopniu zalecenia te, sporządzone na początku XIX w. przez wspomnianego już inspektora szkół ludowych, zostały wdrożone. Faktem jest, że mają one charakter umiejętności niezwykle użytecznych, określających powinności ówczesnych kobiet w rodzinie i społeczeństwie.

${ }^{52}$ BUJ, rkps 5171/36, k. 304.

53 „Porządek na ochędostwie, roztropnym wyborze czasu dla każdej roboty, na naznaczeniu przyzwoitego miejsca każdego sprzętu i każdej rzeczy w gospodarstwie potrzebnej, dobraniu przyzwoitej liczby zdatnej do każdej stosownej posługi czeladzi, zapisaniu każdego sprzętu przybyłego lub ubyłego, na dobrym prowadzeniu rachunków przychodu i wychodu pieniędzy, jasnym pisaniu listów w interesach tyczących się domu". BUJ, rkps 5171/36, k. 304.

54 „Gospodarstwo powinno by się składać z przepisów, które by uczyły jak można zrobić to mniejszym kosztem u siebie, co by kupione daleko więcej kosztowało, jak się robi mydło, krochmal, świece i tym podobne, do gospodarstwa należą roboty ręczne, szycie białe, haftowanie, dzierganie, robienie pończoch, koronek, sukien, tasiemek itp. powinny by tu należyć przepisy znania się na kuchni, na robieniu chleba, octów, wódek przepalaniu, na farbowaniu płócien, nici i bławatów, na dobrem praniu itp. Byłoby rzeczą do żądania, ażeby panienki przeznaczone do życia na wsi znały się na ogrodnictwie, żeby wiedziały, jak się hoduje rośliny potrzebne do kuchni, farbierstwa, przędziwa i do prostych lekarstw, powinny by się prząść na kołowrotkach i kręcić nici nauczyć. Te ostatnie przepisy przystałyby bardziej klasztorom na wsi, gdzie łatwo mieć ogród i gdzie czas poświęcony rozrywkom mógłby być najpożyteczniej obróconym”. BUJ, rkps 5171/36, k. 304. 


\section{Nauka intelektualna}

W XVII i XVIII w. nie obowiązywały żadne odgórne programy nauczania, a zakres przekazywanej wiedzy uzależniony był od woli rodziców oddających córkę na wychowanie oraz umiejętności mistrzyni panien świeckich.

W XVII stuleciu, wzorem poprzednich wieków, praktykowano w niektórych szkołach klasztornych nauczanie elementów łaciny. Odbywało się ono najczęściej poprzez pamięciowe przyswajanie tekstów pieśni religijnych i modlitw, a niekiedy również czytanie treści łacińskich, związanych najczęściej z historią biblijną i pacierzami. Umiejętności te stanowiły podstawę nauczania, pozwalały na aktywny udział w życiu religijnym w środowisku i utrwalały katolicki model wychowania w rodzinie.

Kolejną dziedziną edukacji było uczenie czytania po polsku, a następnie po wydoskonaleniu tej sprawności, nauka pisania liter i cyfr oraz wykonywanie obliczeń arytmetycznych w pamięci.

Od drugiej połowy XVII w. zmianie zaczął ulegać kanon nauczania, głównie pod wpływem sprowadzonych z Francji wizytek oraz benedyktynek-sakramentek. Pomimo oburzenia, jakie pierwotnie okazywali wobec ,panien francuskich” bardziej wpływowi przedstawiciele polskiej szlachty, język francuski powoli stawał się przedmiotem nauczania w szkołach klasztornych prowadzonych przez mniszki z innych zakonów. Jego popularność w drugiej połowie XVII w. rozwijała się najpierw wśród najzamożniejszych i najbardziej wpływowych rodów magnackich, a w kolejnym stuleciu stał się atrybutem wykształcenia nie tylko arystokratek, ale też córek średniozamożnej szlachty. W XVIII w. coraz większe znacznie zaczął odgrywać język niemiecki. Związane to było z objęciem tronu polskiego najpierw przez Augusta II, a potem przez Augusta III, oraz kontaktami z Saksonią. Szczególne wzmożone zapotrzebowanie na naukę tego języka można zaobserwować na terenach sąsiadujących z obszarami niemieckojęzycznymi.

W XVIII stuleciu uczennice w niektórych, bardziej renomowanych szkołach klasztornych uczyły się też elementów geografii i historii, szczególnie biblijnej. Kanon wychowania dziewcząt z bogatych domów stanowiły lekcje nauki gry na instrumentach muzycznych, taniec i rysunki. Zajęcia te były dodatkowo płatne, a więc dostępne tylko dla uczennic zamożnych ${ }^{55}$.

Po zreformowaniu szkolnictwa i wprowadzeniu państwowych programów nauczania zmianie uległ nie tylko sposób, ale też zakres nauczania. Przykładowo, nauka w szkole w Staniątkach obejmowała pod koniec XVIII w., oprócz obowiązkowej nauki języka niemieckiego, który był podzielony na czytanie, pisanie i konwersację, także czytanie i pisanie w języku polskim, religię, arytmetykę, naukę obyczajów i moralności oraz roboty ręczne. Oprócz wymienionych przedmiotów, nauczano też elementarnych wiadomości z geografii, historii, historii biblijnej, a także „lekcyi chimicznych"56.

\footnotetext{
${ }^{55}$ Por. A. Szylar, Działalność wychowawczo-edukacyjna..., s. 214-215. Tam też szczegółowe omówienie realizowanych programów nauczania.

${ }^{56}$ Archiwum Sióstr Benedyktynek w Staniątkach (dalej ABSt.), rkps Szkoła PP. Benedyktynek w Staniątkach, sygn. 1383 , s. 10.
} 
K. Wohlfeil opracował na początku XIX w. dwa projekty nauczania, pierwszy „Plan do wprowadzenia edukacji szlachetnych panien majętnych” i drugi dla dziewcząt uboższych „Uwagi niżej podpisanego nad wychowaniem panienek w klasztorach krakowskich" ${ }^{57}$. Autor świadomie wyróżnił dwie grupy uczennic, i w związku z tym dwa modele kształcenia. Zawsze jednak stał na stanowisku, że edukacja obydwu tych grup dziewcząt była konieczna, różnice dotyczyły wyłącznie zakresu przekazywanej wiedzy. Wychowanki biedniejsze powinny uzyskać bezpłatnie przede wszystkim wiedzę elementarną, najważniejsze zaś było ich wychowanie i nauczenie prac domowych, na które to zajęcia proponował przeznaczyć 2/3 czasu nauki w szkole. W sprawach kształcenia zamożnych dziewcząt wypowiadał się następująco: rodzice majętni moga tak daleko posunać edukacyja, jak im się podoba, lub jak daleko dowcip i zdatność przyrodzone ich córek pozwalają $a^{58}$.

Odrębny plan edukacji opracował dla dziewcząt zamożnych, mieszkających w pensjonatach prowadzonych zarówno przez zakonnice, jak i osoby świeckie. Projekt obejmował cztery klasy, zakres przedmiotów był bardzo rozbudowany, a wszystkie lekcje stanowiły około 50 godzin tygodniowo.

W cyklu kształcenia od pierwszej do czwartej klasy występowały powtarzające się przedmioty, takie jak: religia, język niemiecki, francuski i polski, arytmetyka oraz rysunki, tańce, muzyka i roboty ręczne. Liczba godzin poszczególnych zajęć ulegała zmianie, przy zachowaniu wszystkich wcześniej nauczanych w klasie drugiej znalazła się ponadto w planie nauka moralna i geografia, w trzeciej historia powszechna, w czwartej mitologia oraz fizyka i historia naturalna. Wohlfeil proponował otwarcie klasy piątej tylko w tych szkołach, gdzie będzie zapotrzebowanie na kontynuację edukacji.

Największą rangę w kształceniu dziewcząt zamożnych przypisywano nauce języków obcych, niemieckiego z racji przynależności państwowej i francuskiego jako języka, którym porozumiewano się w wyższych sferach. Przy każdej okazji należało doskonalić umiejętność posługiwania się nimi, pogłębiając znajomość reguł gramatycznych i wymowę. Wohlfeil twierdził, że lekcje powinny być prowadzone po polsku, ale wszystkie omówione zagadnienia należało przetłumaczyć również na języki obce. Przykładowo religii nauczano po polsku, niemiecku i francusku, przy czym trzykrotnie uczono się tych samych treści. Geografia i historia powszechna prowadzona miała być po polsku, ale ten sam temat przerabiano też po francusku ${ }^{59}$.

Władze oświatowe Księstwa Warszawskiego uznawały zasadę, że nauki dla kobiet dawane być maja tylko do stopnia w życiu potrzebnego, nie dla próżnego okazowania obszernych $i$ wysokich wiadomości ${ }^{60}$. Część z nich stanowiła grupę nauk pierwszej potrzeby, osobom wszelkiego stanu i majątku równie potrzebnych, a inne stosować się powinny do stanu i potrzeb kazdej osoby ${ }^{61}$.

\footnotetext{
57 BJ, rkps 5171/36, k. 304-305.

58 Ibidem, k. 304.

59 BJ, rkps 5171/35, 1. 299-300.

${ }^{60}$ Regulament pensji..., s. 517.

${ }^{61}$ Ibidem.
} 
Do niespotykanego wcześniej znaczenia urosło też zagadnienie miłości do ojczyzny, okazywanej przez sumienne wypełnianie obowiązków i nauczanie idei nawiązujących do tego posłannictwa. Elementy wychowania patriotycznego odnajdujemy w następujących przedmiotach i treściach nauczania: tekstach literackich czytanych na języku polskim, na lekcjach historii i geografii.

Program nauczania zawarty w Regulamencie z 1810 r. można podzielić na kilka grup. Pierwszą stanowiły języki - polski, francuski i niemiecki, realizacja ich obowiązywała we wszystkich czterech klasach. Efektem edukacji miała być umiejętność biegłego czytania tekstów pisanych i drukowanych, poprawne pod względem ortograficznym, stylistycznym, gramatycznym, interpunkcyjnym i treściowym pisanie tekstów, precyzyjne wyrażanie myśli w mowie i piśmie. Różnicę programową stanowiła w klasie IV analiza utworów literackich, panny dochodzące czytały wyjątki z dzieł pisarzy polskich i obcych, natomiast pensjonarki miały dodatkowo dla wzbudzenia gustu do czytania [...] dzieła wzorowe, w różnym rodzaju sztuki, tragedie, komedie etc. ${ }^{62}$. Dla tej samej grupy dziewcząt przewidziano w klasie drugiej naukę prowadzenia korespondencji, w tym pisania listów w różnych sprawach. Historię podzielono na biblijną, a ponadto pensjonarki już w klasie pierwszej, a pozostałe uczennice w drugiej, uczyły się historii polskiej, występującej też pod nazwą historii własnego narodu. Historia powszechna miała być realizowana wraz z dziejami polskimi w klasie drugiej. Losy monarchii starożytnych omawiano w klasie trzeciej w szkołach z uczennicami dochodzącymi, te same miały w klasie czwartej historię polską i krajów sąsiednich. Natomiast pensjonarki realizowały w tej samej klasie ostatni z wymienionych przedmiotów oraz kurs historii starożytnej i powszechnej. Im również zalecano wprowadzenie w klasie czwartej „mitologii dla zrozumienia pisarzów", co miało być pomocne podczas czytania utworów literackich, a przede wszystkim sztuk scenicznych ${ }^{63}$.

Realizację wiedzy z zakresu geografii przewidziano w trzech klasach, w pierwszej uczono ogólnego składu i podziału ziemi, w drugiej geografii Polski, przy czym pensjonarki uczyły się jeszcze w tej kasie geografii innych krajów, a dochodzące obszerniejsze informacje z tego zakresu miały w klasie czwartej. Bardziej szczegółową wiedzę, zawierającą ogólne wyobrażenie o geografii niebieskiej, obrotu różnego ziemi, księżyca i innych planet przewidziano tylko dla mieszkanek pensjonatów, program ten realizowano $\mathrm{w}$ klasie trzeciej ${ }^{64}$. W ostatnim roku edukacji wszystkie uczennice zapoznawały się z zagadnieniami z zakresu „znaczniejszych natury fenomenów”, pokazywano im i wyjaśniano osobliwości przyrodnicze, geograficzne i geologiczne, wprowadzano elementy nauk fizycznych, chemicznych i przyrodniczych.

Kurs arytmetyki obejmował liczenie pamięciowe, naukę czterech działań i proporcje, nazywane też regułą trzech ${ }^{65}$. Wiedza $\mathrm{z}$ arytmetyki przekładała się na umiejętności prak-

\footnotetext{
62 Ibidem.

${ }^{63}$ Ibidem.

${ }^{64}$ Ibidem.

65 Jest to reguła pozwalająca obliczyć jedną niewiadomą z proporcji a:b=c:d, gdy pozostałe trzy są dane. Od XV-XVI w. zaczęto stosować ją w Europie w działalności kupieckiej.
} 
tyczne z zakresu prowadzenia ksiąg rachunkowych domowych i kupieckich, uczono tego w klasie drugiej. Dla właściwego prowadzenia buchalterii konieczna była wiedza z zakresu miar, wag i znajomości monet, treści te stanowiły osobny przedmiot przewidziany dla dziewcząt dochodzących w klasie drugiej. Pensjonarki uczyły się tej wiedzy w sposób praktyczny, ale dopiero w klasie czwartej. Zalecano, aby przy jedzeniu uwiadamiać zawsze [...] panny o zmieniajacej się cenie rzeczy do żywności potrzebnych, ich gatunkach, wadze i mierze $e^{66}$. Ponadto każda z pensjonarek powinna wiedzieć cenę każdej rzeczy, która posiada, powinna się znać na gatunku materii, ilości tokci na suknię potrzebnej, na dokładności i cenie roboty. Znać powinny cenę sprzętów stołowych, naczyń kuchennych i spiżarniczych, tudzież mieć wiadomość o porze czasu do nabycia zapasów potrzebnych ${ }^{67}$. Charakter praktyczny miała też historia naturalna, obejmująca wiedzę z ogólnej znajomości zwierząt i szczegółowej roślin, szczególnie tych używanych w konsumpcji i medycynie domowej. Całkowitą nowość stanowiły treści odnoszące się do zachowania zdrowia oraz zagadnienia związane z fizycznym i moralnym wychowaniem dzieci. Wchodziły one w zakres programu realizowanego w dwóch ostatnich latach na$\mathrm{uki}^{68}$. Znaczenie praktyczne miały roboty ręczne, zajęcia prowadzono przez cały cykl kształcenia i obejmowały one szycie, wyszywanie, haftowanie, wykonywanie różnych strojów, w tym damskich sukien. Niezwykle pomocna w tych czynnościach była umiejętność wykonywania rysunków, pensjonarki mogły się uczyć tego przedmiotu jako nadobowiązkowego, a uczennice dochodzące poznawały zasady wykonywania szkiców na zajęciach z robót ręcznych. Zalecano też nauczanie dziewcząt przydatnych umiejętności, takich jak suszenie owoców, warzyw, przypraw kuchennych, ziół i roślin leczniczych oraz wykonywanie konfitur, octów i innych. Istotę przekazywanych wiadomości miały stanowić działania praktyczne, opierające się na treściach zamieszczanych w specjalnych poradnikach, ich wykorzystanie i nauczenie wychowanek posługiwania się nimi miało na przyszłość wdrożyć je do korzystania z tego rodzaju pomocy.

Osobną grupę stanowiły przedmioty tzw. talenty - muzyka, taniec i wymienione wcześniej rysunki, których nauka zalecana była dla pensjonarek wykazujących takie uzdolnienia. Warto podkreślić, że powinnością osób nauczających było poinformowanie rodziców pensjonarki o braku zdolności, aby daremnie panna czasu nie traciła na nabycie nauki, która wkrótce zapomni i zaniedba ${ }^{69}$. Jedynie tańca mogły się uczyć wszystkie dziewczęta, powinnością nauczycieli było zwrócenie uwagi na ukształcenie postawy panien $i$ dobre się trzymanie, jako też na oduczenie powziętych nałogów i przydawanych wdzięków ${ }^{70}$.

${ }^{66}$ Regulament pensji..., s. 517.

${ }^{67}$ Ibidem, s. 518.

${ }^{68}$ Por. D. Żołądź-Strzelczyk, „Edukacja panien świeckich” $w$ klasztorze $w$ Otoboku $w$ XVIII w., w: Cysterki w dziejach i kulturze ziem polskich, dawnej Rzeczypospolitej I Europy Środkowej, red. A. W. Wyrwa, A. Kiełbasa, J. Swastek, Poznań 2004, s. 752-754.

${ }^{69}$ Regulament pensji..., s. 518.

${ }^{70}$ Ibidem. 
Do nadobowiązkowych należało też podawanie wiadomości z zakresu ogrodnictwa i budownictwa wiejskiego, z uwzględnieniem zasad wygodnego i estetycznego urządzenia wnętrz budynków mieszkalnych.

Zakres wiedzy intelektualnej przekazywanej dziewczętom obejmował od przełomu XVIII i XIX w. przedmioty i treści dużo bardziej rozszerzone, aniżeli przed reformą szkolnictwa żeńskiego. Głównym założeniem było połączenie jej z umiejętnościami praktycznymi, które można byloby wykorzystać w życiu codziennym.

Reasumując, można stwierdzić, że przez cały omawiany okres wzorce do życia rodzinnego opierały się na rozwijaniu pobożności i religijności. W oparciu o nie kształtowano moralność i uczono obyczajowości, pogłębiano umiejętności związane z zajęciami przypisanymi kobietom w ówczesnym społeczeństwie. Nauka intelektualna dostosowana była do potrzeb dziewcząt wywodzących się z różnych stanów społecznych i odgrywała podrzędną rolę wobec kształtowania umiejętności i postaw. Celem nauczania było nie tyle zapewnienie kobietom rozległego wykształcenia, co ogólnej wiedzy niezbędnej w życiu codziennym, koniecznej dla właściwego prowadzenia domu, wychowywania dzieci i realizacji wszystkich powinności kobiety, żony i matki.

W regulaminie z XIX w. czytamy na ten temat: Stowem, niedostatek edukacji w damie, jest rzecza najgorsza prawie, gdyż trudno jest bez edukacji grzeczność zachować i ludzkość okazać, a trudniej jeszcze obyczajności dostapić, czyli modestyi lub skromności. Dama bez edukacji chociażby byta najniewinniejsza, najwspanialsza, w kompaniach nie łatwo znaleźć się może, a łatwo może obrazić, czego nie nagrodzi bogactwo ani uroda. Edukacja może zastapić niedostatek bogactw lub urody, a zjednać prawdziwy szacunek damie ${ }^{71}$.

\footnotetext{
${ }^{71}$ AKKr., rkps SzP 10.
} 